\title{
A Diachronic and Source Approach of Phraseological Units - Theories of Definition, Criteria and Structure Analysis in English and Albanian Language
}

\author{
MSc. Lorena Robo \\ PhD candidate, Faculty of Education and Philology \\ English Language Department, University of Korca, Albania \\ I.robo@yahoo.com
}

\section{Doi:10.5901/ajis.2013.v2n9p589}

\section{Abstract}

This study defines and synthesizes the basic and profound nature of phraseological units (idioms) in English and Albanian. It uses descriptive research and analysis of idiom occurrence in both languages and interpretation of their similarities and differences. The findings of this study are given in a detailed and considerable perspective of both languages. It has outlined the typical sources and the diachronic approach of phraseological units, indicating typical characteristics of them. The present paper focuses on the diachronic and resource approach in a comparative way in both languages. The paper aimed at discussing the quality of different approaches of idiom definition and theories from the perspective of two different nation's cultural and geographical outlook. It gives a deep sight in the diachronic approach and analysis of idioms by presenting the main sources in English and Albanian language. It sought to examine the criteria of idiomaticity, stability and word equivalency, idiom motivation, grammatical and lexical valence of words in uniting them into word-groups. The study further relies on principles of classification of idioms. It reports certain features of idioms and it also presents idiom variation in language. This paper discusses the structure analysis of idioms, ways of forming phraseological units as a means of language creativity and nation spiritual reflection. The study further finds the meeting points in languages. It aims to explore the importance of achieving of semantic and structural identity in language.

Keywords: Phraseological units, diachronic approach, source, criteria, analysis, English and Albanian language

\section{Theoretical Background}

The study of idioms in phraseology has been the subject of interest and importance of Albanian and world linguists in the last centuries. They have tried to give a comprehensive and precise approach to the definition of idioms but with certain differences in the main criteria used by them. This article studies idioms which in vocabulary have been approached from different perspectives, the focus of attention varying from form and frozenness (idiom structure) to metaphoricity, and the degree of literalness (idiom meaning). Depending on the emphasis, the definition has accordingly varied from a very strict 'prototypical idioms only' to a very flexible definition effectively identifying any fixed expression in idiomatic language as an idiom. Just as with defining and labeling formulaic language in general, it is difficult if not impossible to reach an agreement on the definition of an idiom. The terms idiom and phraseological unit have been used by linguists as equivalents of one another but a question arises whether they are the same and if they can be used in the place of one another. However, we have the terminology used by the eastern and mainly Russian linguists (A.I.Smirnitsky, V.V. Vinogaradov, etc) who prefer the term phraseological unit and the western (English, Americans) who use the term idiom. Even in Albanian the term phraseological unit has been distinguished from the term idiom considering idioms as highly motivated (frozen) units. This term habitually used by American and English linguists is very often treated as synonymous with the term phraseological unit universally accepted in Albanian.

Phraseological units of all kinds permeate everyday language use throughout all linguistic registers: in everyday speech, journalism, academic prose, literature, political or diplomatic speech and writing, etc. Phraseology plays an important psychological and cultural role in language processing and social cohesiveness. Normal use of phraseological expressions is sometimes self-conscious and creative, at other times uncertain and can also be contentious.

Criteria of phraseological units, classification, and their structure analysis are given by a great number of linguists. The aim of this article is to give an overall perspective view and summarize the main theories of linguists representing their viewpoints and contribution on phraseology till nowadays highlighting the contribution of Albanian phraseology as 
well. It describes as well the sources of phraseological units in both languages concentrating on some hints on the diachronic approach.

\section{Criteria of phraseological units}

Attempts have been made to approach the problem of phraseology in different ways. Till now, there is a certain divergence of opinion as to the essential feature of phraseological units distinguished from other word-groups and the nature of phrases that can be properly termed phraselogical units.

American and English dictionaries of unconventional English, slang and idioms and other highly valuable reference-books contain a wealth of proverbs, sayings, various lexical units of all kinds, but as a rule do not seek to lay down a reliable criterion to distinguish between variable word-groups and phraseological units. Between the extremes of complete motivation and variability of member-words on the one hand, and lack of motivation combined with complete stability of the lexical components and grammatical structure on the other hand, there are innumerable border-line cases. However the existing terms, e.g. set-phrases, idioms, word equivalents, reflect to a certain extent the main debatable issues of phraseology, which center on the divergent views concerning the nature and essential features of phraseological units as distinguished from the so-called free-word groups. The term set-phrase implies that the basic criterion of differentiation is stability of the lexical components and grammatical structure of word groups. The term idiom implies that the essential feature of the linguistic units under consideration is idiomaticity or lack of motivation. The term word-equivalent stresses not only the semantic but also the functional inseparability of certain word-groups and their aptness to function in speech as single words. (Ginzburg, A course in Modern English Lexicology).

Differences in terminology reflect certain differences in the main criteria used to distinguish between free word groups and a specific type of linguistic units generally known as phraseology.

The criteria offered by linguists are idiomaticity, stability, and word-equivalency. Refering to researches of A.V.Kunin he describes the criteria of structural separateness or divisibility of phraseological units into separately structured elements (word or lexemes), e.g. a hard (tough) nut to crack 'a problem difficult to find an answer' can be used in the following forms: They are hard nuts to crack, it is harder nut to crack, the toughest nut to crack.

- Stability is the other important criterion. Kunin distinguishes several aspects of stability: Stability of use, Lexico-semantic stability, Morphological stability- 'play a lone hand, chase the wild goose', but variability is possible in some cases: to be in deep water(s); as happy as king(s), Syntactic stability 'cakes and ale, bread and butter, bread and circus'.

Though phraseological units posses a high degree of stability, their stability is relative. We distinguish phraseological units with high level of stability: 'show the white feather, tit for tat': medium degree of stability: 'the Procrustes' (Procrustean) bed', and low level of stability: 'shed (throw,turn) light (a light) on (upon)'.

Among phraseological units we distinguish partly motivated (a dog in the manager) or non-motivated wordgroups (kick the bucket) is non-motivated. Non-motivation can be explained by the fact that, in course of time, the association between each particular meaning of the component lexemes and the meaning of the whole word combination was faded and lost.

- Functional criterion. A.Smirnitsky considered phraseological units to be word-equivalents because like words phraseological units are introduced into speech as ready-made and function in speech as single words. Phraseological units and words have identical syntactic functions and they are interchangeable in certain contexts. For example throw one's hat in the air 'rejoice', the eye of the day 'the sun'.

Though phraseological units and words have much in common they are different language units. The former is characterized by structural separateness and the later by structure integrity. Phraseological units occupy an intermediate position between words and free-word groups. The difficulties to distinguish between them are enhanced by the fact that salient properties of phraseological units (idiomaticity, stability, and word-equivalency) are expressed in different phraseological units in different degree.

\section{Definition of Phraseological Units (Idioms)}

There are various definitions of phraselogical units (idioms) which reflect certain differences in the main criteria used by different authors. According to A.Kunin, phraseological units are stable word-groups with partially or fully transferred meanings. R.S. Ginzburg defines them as habitually non-motivated word-groups that cannot be freely made up in speech but are reproduced as ready-made units. J.Sedl and W.Mc. Mordie gives the definition as: The idiom is some quantity of 
words which, under condition of their joint consideration, mean something absolutely another in comparison with the individual word meanings, forming an idiom. In Thesaurus dictionary: An idiom is a speech form an expression of a foreign language that is peculiar to it grammatically or cannot be understood from the individual meanings of its element. In Cambridge dictionary: An idiom is a group of words in a fixed order that have a particular meaning that is different from the meanings of each word understood on its own.

According to the well known Albanian linguist Jani Thomaj: An idiom is a linguistic unit with an autonomous meaning consisting of two or more words, with a stable construction, historically formed for a long time, with the value of one word and is reproduced in speech and functions in language as ready-made unit.

As it is seen by the definitions given and others which cannot be quoted for limited for amount of pages in this paper, the concept of ready-made units, the criterion of idiomaticity and stability are the main essential features for their existence. But according to Ginzburg the current definitions have been the subject to criticism. 1) The definitions are felt to be inadequate as the concept ready-made units seem to be rather vague. 2) Frequent discussions have also led to questioning this approach to phraseology from a purely semantic point of view as the criterion of idiomaticity is found to be inadequate guide in singling out phraseological units from other word-groups. $\quad 3$ ) The criterion of stability is also criticized as not very reliable in distinguishing phraseologial units from other word-groups habitually referred to as phraseology. It is observed regular substitution of one of the lexical components. It is also argued that stability of lexical components does not presuppose lack of motivation. In shrug one's shoulders the meaning of words is easily deducible from the meanings of the member-words, hence the word group is completely motivated, though stable. Idiomaticity and stability are not mutually exclusive and may be overlapping, but are not interdependent.

According to Vinogradov he considers phraseological units and lexemes as language units and his main concept is motivation based on Saussure definition. Amosova points out that an idiom is a phraseological unit in which we cannot point out which word comprises the main and basic semantic feature of the unit. According to him both words are key to a contextualized form in such units as grey mare, red herring, and white elephant. According to Reichstein phraseological groups have two different characteristics: regularity in usuage and irregularity in semantic and structural organization (idiomaticity and froziness). He also distinguishes three levels of froziness: absolute, selective, and preferential and eve perfect (come to hell or high water) and imperfect phrases (to cash in one's chips).

\section{Development of Albanian Phraseology}

In Albanian the research on phraseology had been of a later development. We can trace didactic phraseological studies in the beginning of XX century mainly on the practical plan by A. Xhuvani in his work "Mbi thjeshtësinë e gjuhës" (1921) me kallzuem diçka për fije e për pe; me $i$ ardhun nji gjaje pej gëzof, than from Nonda Bulka in his work "Frazeologjia shqipe (lokucionet) in Naim Frashëri work "Histori e Shqipërisë", from M.Çelikut "Togfjalësha të qëndrueshëm foljorë në shqipen e sotme" treats phrases as grammatical and lexical units. I.D.Sheperi (Gramtika dhe sindaksa e gjuhës shqipe, Vlorë, 1927) mentions the term 'lokusion'and includes phrases: marr vesh = kuptoj; kam shkruar = shkrova, në vend të (prepositional word-group). K.Cipo treats them in (Garamatika shqipe, Tiranë, 1949, f. 107) bëka ftohtë, s'është e udhës. J.Rrota includes 153 examples of phraseologcal units in (Sintaksi i Shqipes, Shkodër, 1942, f. 42) like bâj ball, bâj fjalë, baj kambë, baj (e) livadh, etc. M.Domi in (Gramtika e gjuhës shqipe. Pjesa e dytë. Sintaksa, Tiranë, 1957) distinguishes phrases made up of a noun/verb + a preposition like: mbaj mend, kam frikë, ngul këmbë. S.Prifti (Sintaksa e gjuhës shqipe, I, Tiranë, 1962.) gives the syntactic structure of phrases and their semantic value, u bënë afër ( $u$ afruan), bëhuni bashkë, bëra mend etc. The Albanian phraseology had been later studied in 1960's by the lexicological linguist J.Thomaj, who for the first time had given a full treatment of the phraseological units mainly in the theoretical and lexicogrammatical conceptual plan in his monography "Issues of Albanian language phraseology", 1981.

\section{The significance of phraseological change}

According to Ginzburg, the diachronic aspect of phraseology has scarcely been investigated. Just a few points of interest may be briefly reviewed in connection with the origin of phraseological units and the ways they appear in language. It is assumed that almost all phrases can be traced back to free word-groups which in the course of the historical development of the English language have acquired semantic and grammatical inseparability. It is observed that free word-groups may undergo the process of grammaticalization or lexicalization.

Cases of grammaticalization may be illustrated by the transformation of free word-groups composed of the verb have, a noun (pronoun) and Participle II of some other verb into the grammatical form- the Present Perfect in Modern English. The degree of semantic and grammatical inseperability in this analytical word-form is so high that the component 
'have' sees to posses no lexical meaning of its own. This can be observed in such cases of the Present Perfect as have lost where the constituent have is not felt as antonymous with the verb to lose.

The term lexicalization implies that the word-group under discussion develops into a word-equivalent, i.e. a phraseological unit or a compound word. These two parallel lines of lexicalization of free word-groups can be illustrated by the diachronic analysis of, e.g., the compound word instead and the phraseological unit in spite (of).both of them can be traced back to structurally identical free phrases. (Cf. OE. in stede and ME. in despit). The process of lexicaliation may be observed in Modern English too. The noun yesterday, e.g., in the novels by Thomas Hardy occurs as a free wordgroup and is spelled with a break yester-day.

Very little is known of the factors active in the process of the lexicalization of free word-groups which result in the appearance of phraseological untis. This problem may be viewed in terms of degree of motivation. We may safely assume that a free word-group is transformed into a phraseological unit when it acquires semantic inseparability and becomes synchronically non-motivated. There are certain causes accounting for the loss of motivation of free wordgroups such as: a) one of the components results in archaic or drops out of language and the whole word-group may become completely or partially non-motivated e.g. kith and kin, to and fro, b)result of change in the semantic structure of a polysemantic word e.g. to have a mind to do smth, to change one's mind, etc.; c) when a free word-group used in professional speech penetrates into general literary usage, to stick to one's guns, to pull (the) strings (wires), etc. Some extra linguistic factors may cause in loss of motivation to show the white father, $d$ ) when a word-group making up part of a proverb or saying begins to be used as self-contained unit it may gradually become non-motivated e.g. a new broom originates from new brooms sweep clean. e) When part of a quotation from literary sources, mythology or the Bible begins to be used as self-contained unit it may also lose all connection with the original context and as a result of this become non-motivated e.g. the green-eyed monster is found as part of quotation "It is the green-eyed monster which doth mock the meat it feeds on" (Othello, II, i.165).

Apart from contributing to an understanding of phraseology for its own sake, a study of change in word combinations has a broader relevance, as lexical innovation is frequently associated with phraseological patterns. Some neologisms may only be interpretable with reference to existing word combinations: a toothskin marginal (guardian 4/11/91), a phrase coined by a journalist to describe a parliamentary constituency held by a MP with a very small majority, which would be held in an election with difficulty. This can only be understood via knowledge of by the skin of one's teeth. Perhaps fewer newly-coined word combinations become institutionalized than do single words or senses because of their arbitrariness, low frequency and precise cultural associations that make them ephemeral. This leads to important issues of standards and competence: can all phraseological innovations be regarded as 'acceptable' and can all native speakers be regarded as fully phraseologically competent?

According to Howarth, another reason for studying change at this level is that, when reading texts from a previous period, phraseological change (either from or sense) can be obscure in meaning: for example, be in high feather (change in form='be much in evidence') or make love to sb (change in sense= 'to say loving things to someone', used at least until the mid-1950s). Thirdly, in the acquisition of a second language creativity on this level may relate to learning style. Some learners are willing to take risks in experimenting with combinations while others are much more cautious. Finally, while conventionality leads to efficient communication, the phrasal lexicon need to be constantly re-organized and refreshed to remain efficient, in order to reflect and accommodate variability between members of a speech community.

The two main areas that present problems for an understanding of phraseological change are, firstly, distinguishing native change from variation, and, secondly, identifying suitable sources of data for the description of change.

\subsection{Native-speaker variation}

An initial difficulty is to distinguish between intentional, creative variation and unintentional deviation from standard forms. This distinction is clearly necessary in order to understand the creative processes that might lead to change. The chief way is through consideration of the context, medium, genre, register and style: whether the item is spoken or written, from a newspaper headline, formal interview, conversation etc. the more formal and written the style, the more likely it is to be deliberate; non-standard forms found in spontaneous speech are probably unintentional. However, matters are not as simple as that: some items are found in printed sources though the origin may be speech.

In the case of both creative and deviant variation the analytical framework used by linguists such as Mitchell (1966) is useful, categorizing non-standard forms by means of the structural and lexical differences from the standard form they exhibit (transformation, substitution, transposition, expansion and contraction). The category of collocation 'blend' is introduced. The few examples presented here will indicate the broad approach even though the precise details of analysis need not be presented here. 


\subsubsection{Creative variation}

A simmering bone of contention (expansion of bone of contention)

on the ill wind side, his publishers are ordering copies of his 5 books of poetry (contraction of it's an ill wind that blows nobody any good)

$x$ doesn't have courage or conviction to (transformation of have the courage of one's convictions)

Iran snatching defeat from the jaws of victory (transposition of snatch victory from the jaws of defeat)

You look to it like a duck to orange (substitution of duck to water)

No Smoke without Fear or Favour (blend of no smoke without fire/without fear or favour)

\subsubsection{Deviation}

$\begin{array}{ll}\text { His inability to face up to the true music } & \begin{array}{l}\text { (expansion of face the music) } \\ \text { The proof is in the pudding }\end{array} \\ \begin{array}{ll}\text { (contraction of the proof of the pudding is in the eating) } \\ \text { (transformation of slake one's thirst) }\end{array} \\ \begin{array}{ll}\text { Naked act of aggression thirst } & \text { (transposition of act of naked aggression) } \\ \text { Not one of the women battled an eyeball } & \text { (substitution of eyelid) } \\ \text { He gets on my goat } & \text { (blend of he gets on my wick/he gets my goat) }\end{array}\end{array}$

Of the many interesting features of such variation the most significant for the purposes of understanding phraseological change is that many unintentional deviations would pass the average reader or listener unnoticed and many modifications will not be recognized and may therefore slip quietly into usage.

\subsection{Native-speaker historical change}

Having made this initial distinction within phraseological variability, a number of approaches to the identification and description of phraseological change will be outlined.

\subsubsection{An historical continuum}

The first approach returns to the earlier supposedly simple way of introducing change into the model of phraseology and suggest that certain historical processes can be seen to operate in the derivation of idioms.

- Some idioms occur as novel metaphorical expressions that become institutionalized and lexicalized: make up one's mind, put oneself in sb's shoes

- Some are figurative extensions of institutionalized, though literal expressions: build a wall, draw a line

- Some are figurative idioms developed from restricted collocations (semi-idiomatic expressions): take/adopt a stance, draw a veil over sth

- Some have developed into pure idioms from restricted collocations: do justice to, give rise to

These four categories reinforce the impression of a mono-directional, linear historical progression, but while this is informative within a certain defined set of phraseological categories, it does not tell us much about the underlying creative processes that give rise to change across a wider range of categories.

\subsubsection{Informal data collection}

A second approach tends to observe change by analyzing naturally-occurring data on an informal basis. For example the observed collocational deviation abrogate responsibility may indicate collocational change from abdicate responsibility. This may result from the lack of analysis of the combination on the part of speakers, where the meaning of abdicate is not fully analyzed, and whether abdicate or abrogate is used is not noticed. This is likely to occur with low frequency items used in specialized sense and with phonological similarity, and a vague semantic connection may also contribute to the process. These changes may become institutionalized. But with other occurrences like suspend belief used instead of suspend disbelief change is less likely to happen. There may also be changes in form when grammatical collocation is converted to a simple lexeme: sort out changing to sort with the meaning 'arrange/solve'. This only works if the change is currently happening and both forms for a while at least exist simultaneously. 


\subsubsection{Cliché}

The direction in which language develops is towards hyper-conventionality, especially cliché and archaic forms. By definition cliché is a reflection of language change; the speaker is unaware that the expression no longer possesses the figurative force it once had. The stylistic nature of cliché is seen in the fact that a phrase can become instantly a cliché. For example in a UK TV documentary presenter produced the novel expression: explosively productive enterprise and then explosive productivity. It appeared to lose force very quickly and by the third time to be used rather self-consciously.

\subsubsection{Historical research}

In order to find reliable data a more systematic approach is required. The first task is to define an appropriate time span for historical comparison. If the time span is too short, the change may in fact be variation: e.g. Graham Greene "shall we reach Belgrade to time"? (Stamboul Train 1935:135), which is not found in OED. On the other hand if the distance is too great, there may be too much change to isolate what is distinctly phraseological from other changes in the linguistic system.

\section{Data sources}

To describe phraseological change in English we need a body of material containing appropriate instances in sufficient numbers that will make the instances visible. The relevant data will involve quite precise semantic and grammatical as well as stylistic judgement, so it is hard to envisage an entirely corpus based method.

\subsection{Targeted reading}

A novel by Charles Dickens (Barnaby Rudge 1841) and contemporary writings about him are read with the purpose of identifying and noting examples of phraseological change has taken place yielding a useful quantity of data:

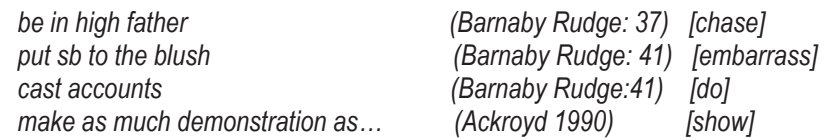

The advantages of this source of data are that language being studied can be guaranteed as authentic and the origin verified. The drawbacks include the problem of distinguishing between what represents the authentic linguistic conventions of the time, and what is part of the author's literary style produced for effect especially in the use of dialogue.

\section{Sources of phraseological units in English and Albanian}

In order to trace the numerous sources of phraseology it is necessary that the research work should go beyond synchronic approach into diachronic as well as ethnography, folklore, history, etc. the study of social element helps to motivate the phraseological units and trace their sources mainly through non-linguistic factors. The sources are of a great number and as any lexical item they can be either native English by origin or borrowed from other languages. Most of them as in Albanian are native which reflect traditions, customs, beliefs, myths, historical facts, personalia, etc.

- phraseological units derived from historical events: pay through the nose, to burn one's boats, u grindën për mustaqet e Çelos' from folklore: 'I thotë që fët për fët unë të vras' from ancient mythology: open Pandora's box, a Trojan horse from traditions and customs: to sit above the salt, tie the knot from household items: sytë dollap $i$ ka from plants: fle mbi dafina from animals and body parts: thashethemet nuk kanë brirë numbers: s'gjindet dele me pesë këmbë atmosphere: është si bryma pas diellit groceries: bukë e krypë e zemër insects, poultry, reptiles: puna jote si zog në qiell astronomy: u poqi ylli të dyve from the names of people: a peeping Tom, për mustaqet e Çelos professional activity: agriculture-to break ground; industry: a blue-collar worker the sea: in deep water; fishing: to fish for compliments; $>$ military sphere: fall into line, me fishekë në brez; sports: keep the ball rolling; music: play the first fiddle; painting: the dark side of the picture; business: bring to account $>$ phoning someone: to phone someone up buying and selling: to bring something under the hammer playing cards and gambling: throw good money after bad banking: the bank dishonours a cheque parts of body: after one's own heart, hiqmu nga sytë, 
literary origin: cakes and ale, 'Çohuni! për ndryshe jua hodha trutë në erë! from authors: e.g J.Chaucer: through thick and thin from bible: as old as Methuselah from death, illness, health: he is/looks the picture of health, është si kokrra e mollës politics: the shadow Cabinet from animals: to make a bee-line for something colours: to give someone the green light other languages, italian, german, french, latin: every dog is a lion at home, blood and iron, bon voyage, e pluribus unum with a Turkish lexeme: nuk lëviz xhanxhi njeriu from fairy-tales: Aladdin's lamp americanisms: cut a pie contacts: all roads lead to Rome professions: i nxjerr rrënjën katrore dialects from Korça: duhet të kesh dy barqe me dikë: një ta çash, një ta mbash $>$ religious sphere: 'vë kurorë' physics: pikë e vdekur anatomy: shtylla kurrizore zoology: nusja e lalës $>$ political-social sphere: përpiqet të vërë botën nën thundër' astronomy: Kashta e Kumtrit', etc.

The sources of phraseological units are numerous in both languages. Both of them have sources from different fields of life most of which are related with traditions, folklore, phraseological units derived from authors and literary works, mythology, beliefs, historical facts, etc. Phraseological units derived from agriculture and agriculture tools, farming, landing are sources which mainly dominate in Albanian phraseology reflecting though spiritual mentality of a nation's language. A small number of phraseological units are seen in Albanian compared with the English language concerning sports, business, gambling, sea and the life of seamen. However it is crucial to confirm that phraseology is the reflection of the social and psychological attribute in language processing and social cohesiveness in both languages, it changes, slips and is each day enriched as to affirm that "Language is a living thing" (J.Sedl and W.Mc. Mordie).

\section{Conclusion}

Phraseology plays an important psychological and cultural role in language processing and social cohesiveness. Normal use of phraseological expressions is sometimes self-conscious and creative, at other times uncertain and can also be contentious.

Various definitions of phraselogical units (idioms) which reflect certain differences in the main criteria used by different authors had been presented concluding in somewhat the same definition of phraseological units, characterized by elements of stability and idiomaticity, inseperability and word-equivalency. The aim of this study was to give some hints into the diachronic aspect of phraseology which has scarcely been investigated. Just a few points of interest had been briefly reviewed in connection with the origin of phraseological units and the ways they appear in language. All phrases can be traced back to free word-groups which in the course of the historical development of the English Language have acquired semantic and grammatical inseparability.

The sources of phraseological units are numerous and may dominate mostly in one language or the other. They are treated briefly in both languages derived from different sources and fields of life most of which are related with traditions, folklore, phraseological units derived from authors and literary works, mythology, beliefs, historical facts, sports, gambling, the life of sea and seamen, agriculture, politics, economy, bible, parts of body, industry, military sphere, etc.

Among the problems that remain in studying the diachronic approach of idioms is the difficulty of making confident judgements of meanings that existed in the past in English and Albanian language since the origin of phraseological units and the way they have entered a language remains unknown. The chief drawback of the methods used to the historical change of occurrences is that the chances of finding enough examples of an individual phraseological item that observably changes in meaning, form and style over a certain period are slim. It is difficult to trace back the etymology of a phraseological unit through history of development and no Albanian linguist till and up would give for sure the tracing of phraseological units in a diachronic approach.

\section{References}

Aitchison, J. 1991. Language Change. Cambridge: Cambridge University Press.

Akroyed,P.(1990). Dickens. London: Minerva.

Cowie, A.P. 1988. "Sable and creative aspects of vocabulary use", in R.Carter and M.McCarthy (eds.) 1998. Vocabulary and Language Teaching London: Longman. 126-139.

Everaert. M. (1995).Idioms: structural and psychological perspectives, Lawrence Erlbaum Associates, Inc., Publishers.

Ginzburg R. S. et al. (1079).A Course in Modern English Lexicology, M.

Gläser, R. 1988."The grading of idiomaticity as a presuposition for a taxonomy of idioms", in W. Hüllen and R.Schulze (eds.) 1998. Understanding the Lexicon: Meaning, Sense and world Knowledge in Lexical Semantics. Tübingen: Max Niemeyer. 264-279.

J.Sedl and W.Mc. Mordie.(1978). English idioms and how to use them, Oxford University Presss,

Mc.Carthy, O'Dell.F.(1994). English idioms in use, Cambridge University Press. 
Pawley, A. "Lexicalization", in D.Tannen and J. Alatis (eds.) 1985. Language and Linguistics: the Interdependence of Theory, Data and Application. Washington DC: University of Georgetown, 98-120.

Strässler.J : Norr. (1982) Idioms in English; A pragmatic analysis.

Thomai.J.(2010). Fjalor frazeologjik i gjuhës shqipe, Tiranë.

Thomai.J. (1981).Çështje të frazeologjisë së gjuhës shqipe. Tiranë. 